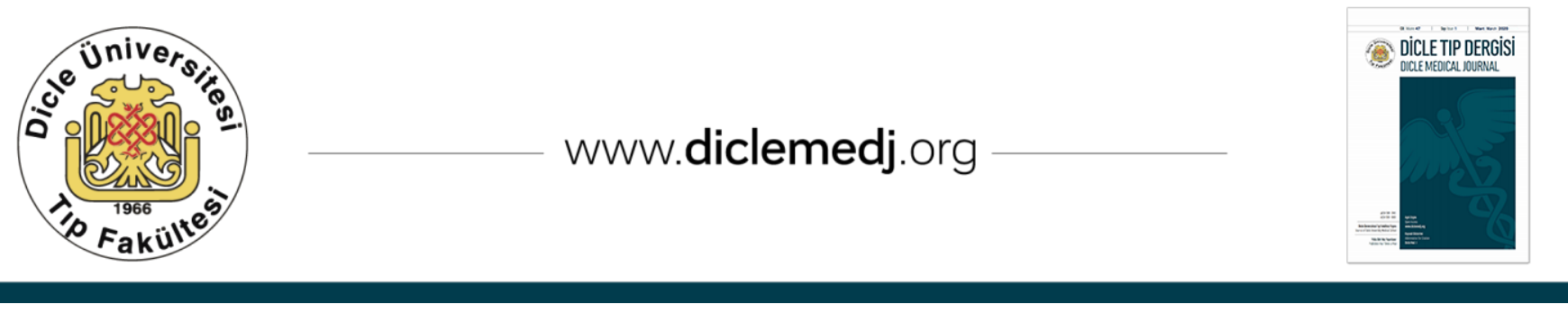

\title{
Kliniğimizde Cerrahi Olarak Tedavi Edilen Göz Kapağı Tümörlerinin Histopatolojik Bulguları
}

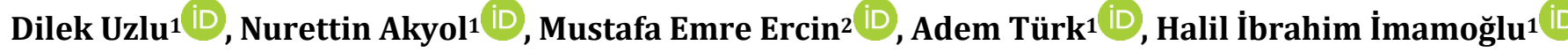 \\ 1 Karadeniz Teknik Üniversitesi, Tıp Fakültesi, Göz Hastalıkları Anabilim Dall, Trabzon, Türkiye \\ 2 Karadeniz Teknik Üniversitesi, Tıp Fakültesi, Patoloji Anabilim Dal, Trabzon, Türkiye \\ Geliş: 05.08.2019; Revizyon: 18.02.2020; Kabul Tarihi: 19.02.2020
}

$\ddot{0} \mathbf{z}$

Amaç: Göz kapağından kitle eksizyonu yapılan olguların klinik ve histopatolojik sonuçlarını değerlendirmek

Yöntemler: Ocak 2009-Eylül 2018 tarihleri arasında göz kapağından total kitle eksizyonu yapılan 109 hastanın klinik ve histopatolojik sonuçları retrospektif olarak incelendi. Olguların yaşı, cinsiyeti, kitlenin yerleşim yeri, boyutu ve histopatolojik tanıları kaydedildi.

Bulgular: Yaş ortalaması 54,07 (1-88) olan 54 (\%49,5) 'ü erkek, 55 (\%50,5) 'i kadın 109 hasta çalışmaya dâhil edildi. Eksize edilen kitlelerin $75(\% 68,8)$ 'i benign, $5(\% 4,6)$ 'i premalign ve $29(\% 26,6)$ 'u malign idi. Tümör yerleșim yerine bakıldığında göz kapağı benign tümörleri en sık üst kapakta izlenirken $(\% 46,7)$, premalign ve malign göz kapağı lezyonları sıklıkla alt kapakta $(\% 75,9)$ yerleşim göstermekteydi. Göz kapağında sık görülen benign tümörler sırasıyla skuamöz papillom $(\% 13,8)$, epidermal kist $(\% 12,8)$, intradermal nevüs $(\% 10,1)$ ve seboreik keratoz $(\% 10,1)$ idi. Benign göz kapağı tümörlerinde yaş ortalaması 47,9 (1-85) ve ortalama tümör boyutu 0,66 (0,2-3) cm idi. En sık görülen malign göz kapağı tümörü \%20,2 oranında bazal hücreli karsinom idi. Bazal hücreli karsinomların \%63,7'si kadın olup, yaş ortalaması 68,2(45-87) idi. Göz kapağı lezyonlarından bazal hücreli karsinom $(\% 63,6)$ ve intradermal nevüs $(\% 72,7)$ kadınlarda daha sık izlenirken, epidermal kist $(\% 64,3)$, seboreik keratoz $(\% 72,7)$ ve skuamöz papillom $(\% 66,7)$ erkeklerde daha fazla izlenmekteydi.

Sonuç: Kliniğimizde en sık cerrahi tedavi uygulanan benign göz kapak tümörü skuamöz papillom, malign göz kapağı tümörü ise bazal hücreli karsinom idi. Malign tümörler sıklıkla ileri yaşlarda gözlenmekle beraber genç orta yaşta da görülebileceğinden, eksize edilen tüm kitleler patolojik olarak değerlendirilmelidir.

Anahtar kelimeler: Göz kapağı tümörleri, karsinom, bazal hücre, patoloji.

DOI: $10.5798 /$ dicletip.706116

Yazıșma Adresi / Correspondence: Dilek Uzlu, Karadeniz Teknik Üniversitesi Tıp Fakültesi Göz Hastalıkları A.D. 61080-Trabzon, Türkiye e-mail: dilenkh@hotmail.com 


\title{
Histopathological Findings of Eyelid Tumors Treated Surgically in Our Clinic
}

\begin{abstract}
Objective: To evaluate the clinical and histopathological results of eyelid tumors.

Material and Methods: Clinical and histopathological results of 109 patients who underwent mass excision from the eyelid were retrospectively analyzed, between January 2009 and September 2018. Age and sex, tumor localization, dimension and histopathological diagnosis of the patients were recorded. Results: A total of 109 patients (54 male, 55 female) with a mean age of 54.07 (1-88) were included in the study. When the histopathological results of excised eyelid tumors are evaluated; 75 (68.8\%) of them were benign, 5 (4.6\%) were premalignant and 29 (26.6\%) were malignant. Eyelid benign tumors were most commonly seen in the upper eyelid (46.7\%), whereas premalignant and malignant eyelid lesions were frequently localized in the lower eyelid (75.9\%). Histopathological diagnoses of common benign eyelid tumors were as follows squamous papilloma (13.8\%), epidermal cyst (12.8\%), intradermal nevi (10.1\%) and seborrheic keratosis $(10.1 \%)$. The mean age of the benign eyelid tumors was $47.9(1-85)$ and the mean tumor size was $0.66(0.2-3)$ $\mathrm{cm}$. The most common malignant eyelid tumor was basal cell carcinoma (20.2\%). The mean age of basal cell carcinoma was $68.2(45-87)$ and $63.7 \%$ of them were females. Basal cell carcinoma (63.6\%) and intradermal nevi (72.7\%) were more common in women while, epidermal cyst (64.3\%), seborrheic keratosis (72.7\%) and squamous papilloma (66.7\%) was more seen in males. Conclusion: In our clinic, the most common surgical treatment of benign eyelid tumor was squamous papilloma and the most common malignant eyelid tumor was basal cell carcinoma. Although malignant tumors are frequently observed in older ages, all excised masses should be evaluated as pathological since they can be seen in young middle age.
\end{abstract}

Keywords: Eyelid neoplasms, carcinoma, basal cell, pathology.

\section{GíRiș}

Göz kapağı ultraviyole ışınlar gibi dış etkenlere sıklıkla maruz kaldığından oftalmoloji pratiğinde görülen tümörlerin çoğunluğu bu bölgelerde oluşmaktadır ${ }^{1,2}$. Göz kapaklarındaki kitleler göz kapağında bulunan tüm dokulardan kaynaklanabilsede en sık cilt kaynaklıdır³. Göz kapağında sıklıkla benign tümörler görülmekte olup çoğuna klinik görünümleri ile tanı koyabilmek mümkündür. Benign tümörler kozmetik ve işlevsel bozukluklara neden olurken, malign tümörler tüm vücuda yayılım yaparak hayatı tehdit edici durumlara neden olabilmektedir. $\mathrm{Bu}$ yüzden benign ve malign tümörlerin ayırıcı tanılarının iyi yapılması büyük önem taşımaktadır ${ }^{4}$. Özellikle bazı malign tümörler klinik görünümleri ile benign tümörleri ve inflamatuar değişiklikleri taklit edebildiğinden kesin tanı ancak histopatolojik inceleme ile belirlenebilmektedir ${ }^{5,6}$. Bu nedenle klinik olarak benign tümör düşünülsede eksize edilen tüm kitleler histopatolojik olarak değerlendirilmelidir.

Çalışmamızda göz kapağında kitle şikâyeti ile başvuran hastalardan elde edilen eksizyonel biyopsi materyalleri değerlendirilerek; kapak tümörlerinin sıklığl, klinik ve histopatolojik özellikleri incelenmiştir.

\section{YÖNTEMLER}

Çalışmamız için Etik Kurul onayı alındı ve çalışma Helsinki Bildirgesi'ne uygun olarak yürütüldü. Göz kapağında kitle nedeni ile Ocak 2009-Eylül 2018 tarihleri arasında Karadeniz Teknik Üniversitesi Tıp Fakültesinde total kitle eksizyonu yapılan ve patolojik değerlendirmesi olan 109 olgunun klinik ve histopatolojik sonuçları retrospektif olarak değerlendirildi. Çalışmaya total kitle eksizyonu yapılmayan, şalazyon gibi inflamatuar kitlesi olan ve histopatoloji sonucuna ulaşılamayan olgular dahil edilmedi. Olguların yaşı, cinsiyeti, kitlenin yerleşim yeri, boyutu ve histopatolojik tanıları 
kaydedildi. Tüm olguların patolojik incelemeleri hastanemiz tıbbi patoloji kliniğinde yapıldı. Kitlenin boyutu hesaplanırken patolojiye gönderilen materyalin en-boy-derinlik boyutlarından en büyük olanı göz önüne alındı. Cerrahi yapılan bütün hastalara eksizyonel biyopsi uygulandı.

\section{BULGULAR}

Çalışmamıza göz kapağından total kitle eksizyonu yapılan ve patolojik değerlendirmesi olan 109 hasta dâhil edildi. Olguların 54 $(\% 49,5)$ 'ü erkek, $55(\% 50,5)$ 'i kadın hasta olup ortalama yaş 54,07 (1-88) idi. Kitlelerin 83 $(\% 53,5)$ 'ü sağ, $72 \quad(\% 46,4)$ 'si sol gözde yerleşimli idi. Kitlelerin $50(\% 45,9)$ 'si alt kapak, $43(\% 39,4)$ 'ü üst kapak, $14(\% 12,8)$ 'ü iç kantus ve $2(\% 1,8)$ 'si diş kantus yerleşimli idi. Göz kapağındaki lezyonların $75(\% 68,8)$ 'i benign, 5 $(\% 4,6)$ 'i premalign ve $29(\% 26,6)$ 'u malign idi. Göz kapağı benign tümörleri en sık üst kapakta izlenirken $(\% 46,7)$, premalign ve malign göz kapağı lezyonları sıklıkla alt kapakta yerleşim $(\% 75,9)$ göstermekteydi. Benign göz kapağ tümörlerinde yaş ortalaması 47,89 (1-85) olup ortalama tümör boyutu $0,66(0,2-3) \mathrm{cm}$ idi. Göz kapağında en sık görülen benign tümör 15 $(\% 13,8)$ hasta ile skuamöz papillom idi. Bunu 14 hasta $(\% 12,8)$ ile epidermal kist, $11(\% 10,1)$ hasta ile intradermal nevüs ve seboreik keratoz takip etmekteydi. Benign kapak tümörlerinden intradermal nevüs $\% 72,7$ oranında kadınlarda daha fazla rastlanırken, skuamöz papillom $\% 66,7$, seboreik keratoz $\% 72,7$ ve epidermal kist \%64,3 oranında erkeklerde daha fazla izlendi.

En slk izlenen premalign göz kapağı tümörü 3 $(\% 2,7)$ hastada aktinik keratoz iken, bunu 2 $(\% 1,8)$ hasta ile skuamöz hücreli karsinoma insitu takip etmekteydi. Malign göz kapağ tümörlerinde yaş ortalaması 68,65 (45-87) ve ortalama tümör boyutu 1,05 (0,3-2) cm idi. En sık görülen malign göz kapağı tümörü Bazal hücreli karsinom $(\mathrm{BHK})(\% 20,2)$ idi. Bazal hücreli karsinomların yaș ortalaması 68,22 (4587) olup \%63,6'sı kadın idi. Yerleşim yerine bakıldığında bazal hücreli karsinomların 16 $(\% 72,7)$ 'sı alt kapak, $4(\% 18,2)$ 'ü iç kantus ve 2 $(\% 9,1)$ 'si üst kapak yerleşimli olup ortalama tümör boyutu $1(0,3-2) \mathrm{cm}$ idi. Kliniğimizde alt göz kapağından bazal hücreli karsinom eksizyonu yapılan hastanın makroskopik ve histopatolojik görüntüleri Resim 1'de izlenmektedir. Malign göz kapak tümörlerinde ikinci slklıkta sebase karsinom $(\% 1,8)$ ve skuamöz hücreli karsinom $(\% 1,8)$ izlendi.

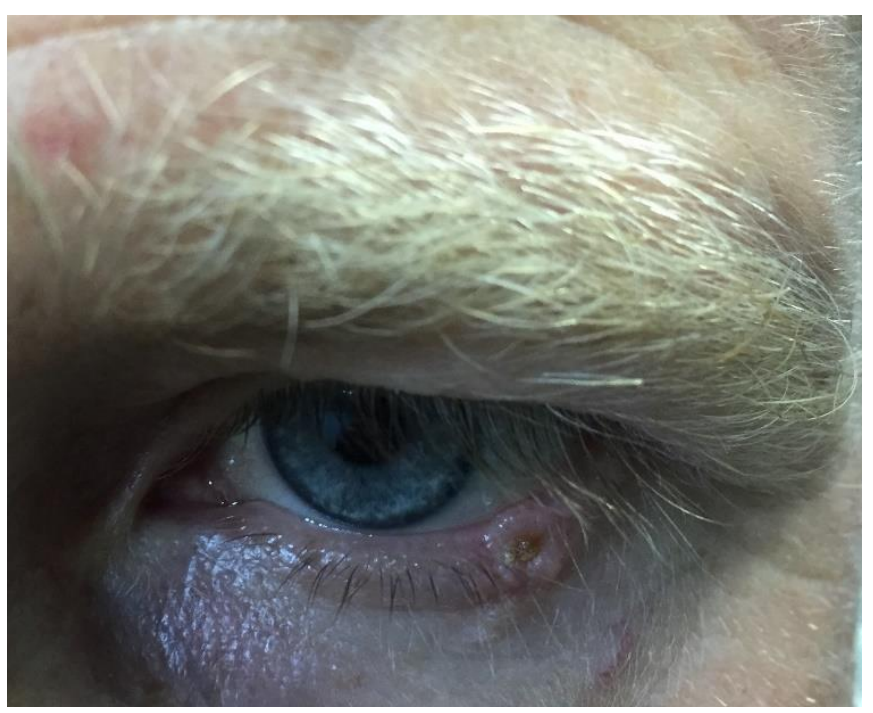

Resim 1a

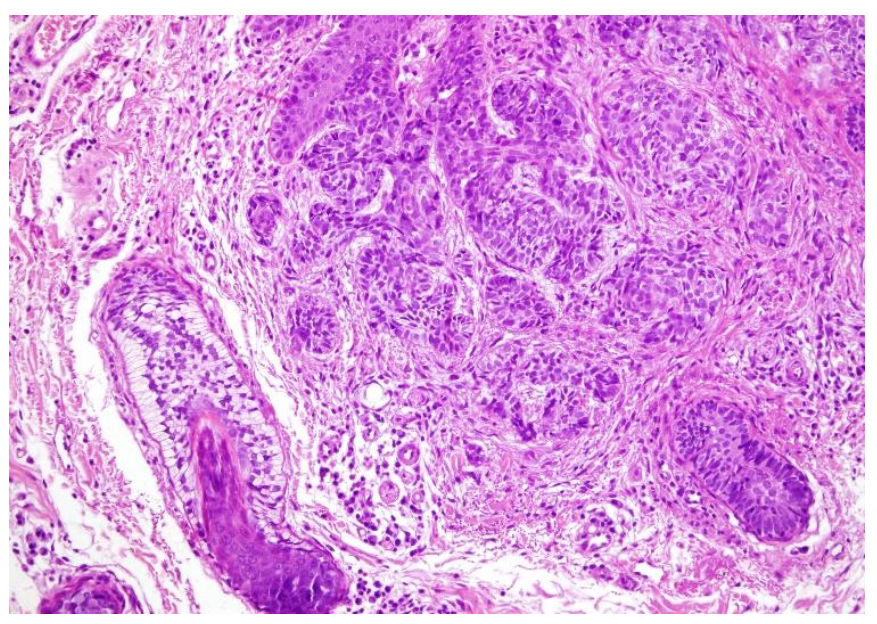

Resim 1b

Resim 1. Alt göz kapağında yerleșim gösteren Bazal hücreli karsinomun makroskopik (1a) ve histopatolojik görünümü (1b). Histopatolojik görüntüde palizatlanma ve retraksiyon artefaktı gösteren tümör adaları izlenmektedir (1b) (Hematoksilen Eosin;X200). 
Kliniğimizde alt göz kapağından eksize edilen sebase hücreli karsinom ve skuamöz hücreli karsinoma ait makroskopik ve histopatolojik görüntüler sirasiyla Resim 2 ve 3 'de izlenmektedir. Çalışmamızdaki göz kapak tümörlerinin sayısı, bütün tümörler içindeki oranı, görülme yaşı ve yaş aralı̆̆ı, cinsiyet dağılımı ve kapak yerleşim yeri Tablo 1'de görülmektedir.

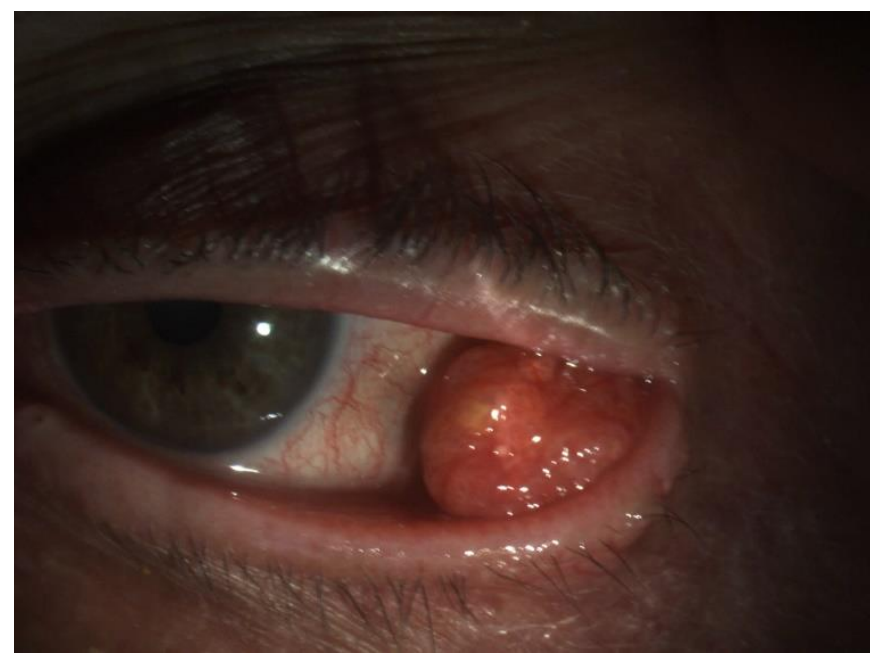

Resim 2a

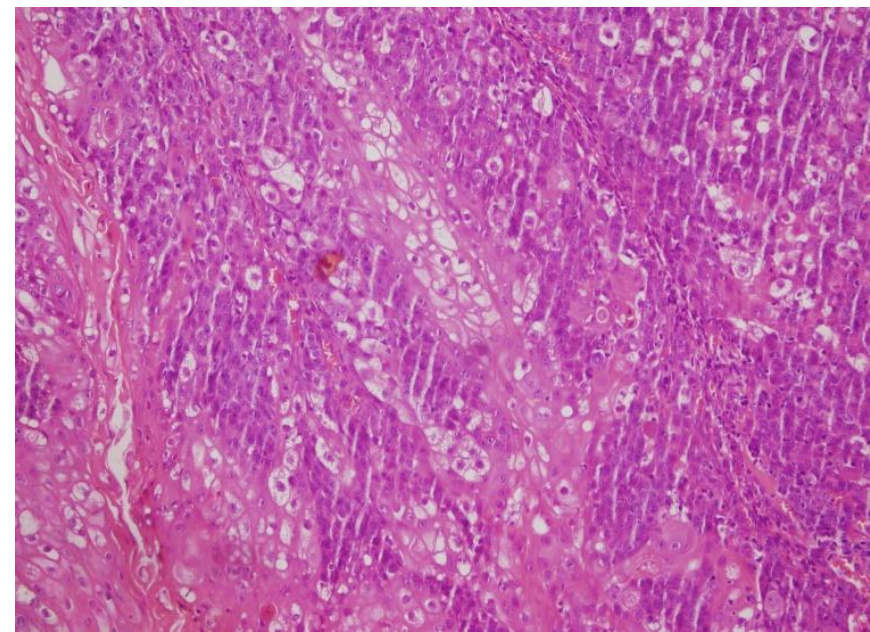

\section{Resim 2b}

Resim 2. Alt göz kapağında yerleşim gösteren Sebase karsinomun makroskopik (2a) ve histopatolojik görünümü (2b). Histopatolojik görüntüde nükleer pleomorfizm ve hiperkromazi içeren sebase hücrelerin oluşturduğu tümöral proliferasyon izlenmektedir (2b) (Hematoksilen Eosin;X200).

Kitlelerin klinik ön tanıları ve histopatolojik sonuçları karşılaştırıldığında; klinik ön tanısı benign düșünülen 84 kitlenin $4 \quad(\% 4,7)^{\prime}$ ü premalign ve 5 'i malign $(\% 5,9)$ olarak patolojide değerlendirildi. Kitlelerinden sebase kist ön tanılı iki lezyon sebase karsinom, papillom ön tanılı iki lezyon bazal hücreli karsinom ve hemanjiom ön tanılı 1 kitle kaposi sarkomu olarak değerlendirildi. Papillom ön tanılı üç lezyon aktinik keratoz, nevüs ön tanılı bir lezyonda patolojide skuamöz hücreli karsinoma in situ olarak değerlendirildi.

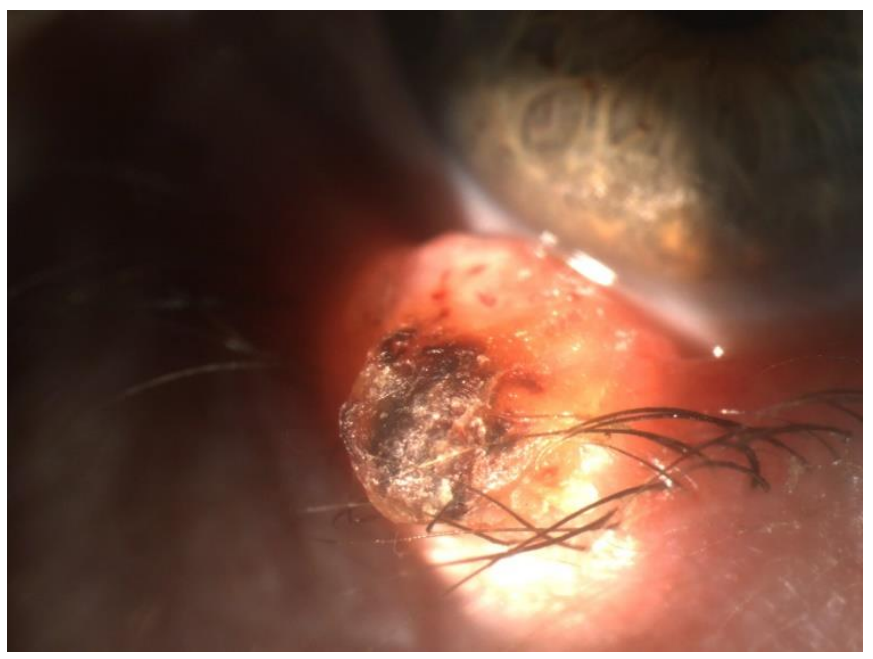

Resim 3a

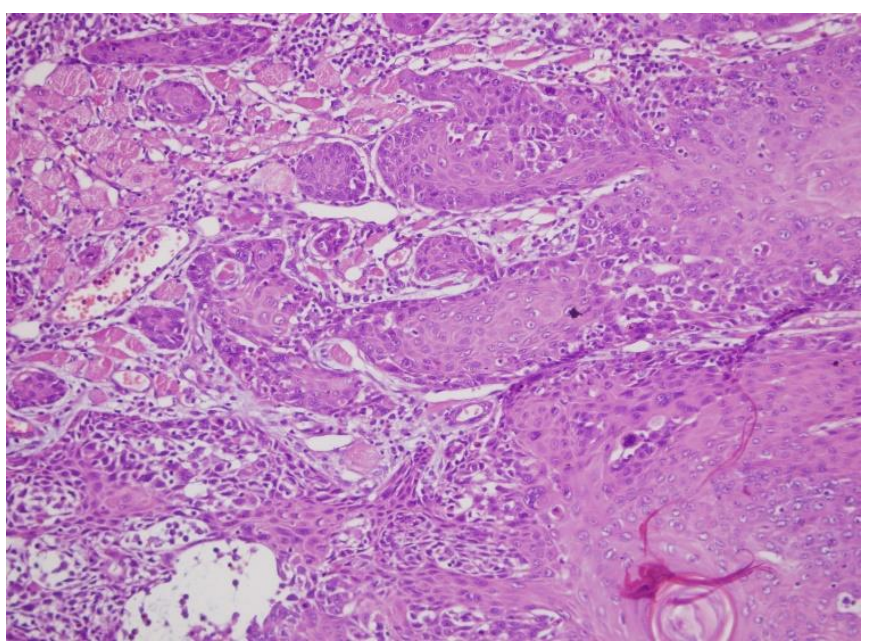

Resim 3b

Resim 3. Alt göz kapağında yerleșim gösteren Skuamöz hücreli karsinomun makroskopik (3a) ve histopatolojik görünümü (3b). Histopatolojik görüntüde akantoliz, nükleer atipi ve keratin incileri içeren skuamöz epitel proliferasyonu izlenmektedir (4b) (Hematoksilen Eosin;X200). 
Uzlu D., Akyol N., Ercin M.E., Türk A., İmamoğlu H.í.

Tablo 1: Çalışmaya dâhil edilen kapak tümörlerinin klinik ve histopatolojik özellikleri

\begin{tabular}{|c|c|c|c|c|c|c|c|c|c|c|c|}
\hline Patolojik tanı & Sayı & $\begin{array}{c}\text { Oran } \\
(\%)\end{array}$ & Yaş Ort. & $\begin{array}{c}\text { Yaş } \\
\text { Aralığı }\end{array}$ & Erkek & Kadın & Boyu (cm) & $\begin{array}{c}\text { Alt } \\
\text { Kapak }\end{array}$ & $\begin{array}{c}\text { Üst } \\
\text { kapak }\end{array}$ & $\begin{array}{c}\text { İç } \\
\text { kantus }\end{array}$ & $\begin{array}{c}\text { Diş } \\
\text { kantus }\end{array}$ \\
\hline Bazal Hücreli Karsinom & 22 & 20,2 & 68,22 & $45-87$ & 8 & 14 & $1(0,3-2)$ & 16 & 2 & 4 & \\
\hline Skuamöz papillom & 15 & 13,8 & 53,67 & $15-85$ & 10 & 5 & $0,46(0,3-0,9)$ & 10 & 4 & 1 & \\
\hline Epidermal kist & 14 & 12,8 & 39,5 & $1-63$ & 9 & 5 & $0,84(0,1-2,5)$ & 2 & 9 & 3 & \\
\hline İntradermal nevüs & 11 & 10,1 & 53,45 & $29-69$ & 3 & 8 & $0,46(0,2-0,8)$ & 5 & 5 & 1 & \\
\hline Seboreik keratoz & 11 & 10,1 & 58,18 & $43-70$ & 8 & 3 & $0,57(0,2-1)$ & 2 & 7 & 2 & \\
\hline Basit duktal kist & 8 & 7,3 & 58,62 & $39-77$ & 5 & 3 & $0,87(0,1-3)$ & 4 & 3 & & 1 \\
\hline Kapiller hemanjiom & 4 & 3,7 & 23,25 & $1-63$ & 2 & 2 & $0,42(0,1-1)$ & & 3 & & 1 \\
\hline Dermoid kist & 4 & 3,7 & 7 & $2-15$ & & 4 & $0,72(0,5-1)$ & 1 & & 3 & \\
\hline Aktinik keratoz & 3 & 2,7 & 65,67 & $42-78$ & & 3 & $0,5(0,3-0,7)$ & & 3 & & \\
\hline Bowen & 2 & 1,8 & 58,5 & $51-66$ & 1 & 1 & $0,5(0,4-0,6)$ & 1 & 1 & & \\
\hline Sebase karsinom & 2 & 1,8 & 61,5 & $36-87$ & 1 & 1 & $0,9(0,6-1,2)$ & 1 & 1 & & \\
\hline $\begin{array}{c}\text { Skuamöz hücreli } \\
\text { karsinom }\end{array}$ & 2 & 1,8 & 70 & $65-75$ & 2 & & $1,35(0,7-2)$ & 1 & 1 & & \\
\hline Verruka vulgaris & 2 & 1,8 & 57,5 & $35-80$ & & 2 & $0,3(0,3-0,3)$ & & 2 & & \\
\hline Fibroepitelyal polip & 2 & 1,8 & 34 & $5-63$ & 1 & 1 & $0,5(0,4-0,6)$ & 2 & & & \\
\hline Kaposi sarkomu & 1 & 0,9 & 59 & & 1 & & 0,8 & 1 & & & \\
\hline Kavernöz hemanjiom & 1 & 0,9 & 57 & & & 1 & 1,8 & & 1 & & \\
\hline $\begin{array}{l}\text { Noduler malign } \\
\text { melanom }\end{array}$ & 1 & 0,9 & 88 & & & 1 & 3 & 1 & & & \\
\hline $\begin{array}{c}\text { Ekstranodal marjinal zon } \\
\text { lenfoma }\end{array}$ & 1 & 0,9 & 80 & & 1 & & 1 & 1 & & & \\
\hline Anjiomiksoma & 1 & 0,9 & 26 & & & 1 & 2,5 & & 1 & & \\
\hline Sudoriferöz kist & 1 & 0,9 & 67 & & 1 & & 1,5 & 1 & & & \\
\hline Trikoepitelyoma & 1 & 0,9 & 83 & & 1 & & 0,5 & 1 & & & \\
\hline
\end{tabular}

\section{TARTIŞMA}

Göz kapağında yerleşimli kitleler çoğunlukla benign karakterde olup yavaş büyüme eğilimi göstermektedir7 ${ }^{7}$. Görülme yaşı sıklıkla orta-ileri yaş olup, hastalar kliniğe daha çok kozmetik kaygılarla başvurmaktadırlar. Eksize edilen kitlelerin histopatolojik incelemesi tanı ve tedavinin en önemli kısmını oluşturmaktadır. Çalışmamızda göz kapağındaki lezyonların $\% 68,8$ 'i benign, $\% 4,6$ 's 1 premalign ve $\% 26,6$ 's malign olarak değerlendirildi. Ülkemizde yapılan diğer çalışmalarda Erdoğan ve arkadaşları benign göz kapak tümör oranını
$\% 68,9$, malign tümör oranını \%31,1 olarak; Gündoğan ve arkadaşları ise benign göz kapak tümörü görülme oranını \%92,5, premalign tümör oranını $\% 6$ ve malign tümör oranını $\% 1,5$ olarak bulmuşlardır8,9. Literatürdeki en geniş serilerden biri olan Deprez ve arkadaşlarının 5504 olgudan oluşan çalışmasında göz kapağı tümörlerinin $\% 84$ 'ünün benign, $\% 16$ ' sının malign lezyonlardan oluştuğunu bildirmişlerdir ${ }^{10}$. $\mathrm{Xu}$ ve arkadaşları çalışmalarında 2639 olgunun \%86,2'sini benign \%13,8'ini malign; Pornpanichk ve arkadaşları ise 297 olgunun \%71,4' ünün benign, \%10,8' 
inin ise malign lezyonlardan oluștuğunu bildirmișlerdir ${ }^{11,12}$.

Çalışmamızda göz kapağı benign tümörleri içerisinde en sık görülen tümör skuamöz papillom $(\% 13,8)$ olup, daha çok alt kapakta ve erkeklerde izlenmekteydi. Ülkemizde yapılan diğer çalışmalara bakıldığında Erdoğan ve arkadaşları skuamöz papillom görülme oranını \%13,7, Gündoğan ve arkadaşları \%21,8, Uzun ve arkadaşları ise $\% 19$ olarak bildirmişlerdir8,9,13. Çalışmamızda ikinci sıklıkta görülen benign kapak tümörü epidermal kist $(\% 12,8)$ olup daha çok erkeklerde ve üst kapakta yerleşim göstermekteydi. Erdoğan ve arkadaşları yapmış oldukları çalışmada epidermal kist görülme oranını \%17,6, erkeklerde ve üst kapakta daha sık görüldügünü bildirmişlerdir8. Çağlar ve arkadaşları yapmış oldukları çalışmada epidermal kist görülme oranını \%9,7 ve erkeklerde daha sık görüldüğünü bildirmişlerdir ${ }^{14}$. Çalışmamızda intradermal nevüs görülme oranı $\% 10,1$ olup kadınlarda daha sık görülmekte idi. Erdoğan ve arkadaşları yapmış oldukları çalışmada intradermal nevüs oranını \%23,5, Uzun ve arkadaşları \%19, Çağlar ve arkadaşları ise \%20 oranında ve kadınlarda daha sık izlendiğini bildirmişlerdir $8,13,14$.Çalışmamızda seboreik keratoz görülme oranı \%10,1 olup, erkeklerde daha sık görülmekte idi. Erdoğan ve arkadaşları yapmış oldukları çalışmada seboreik keratoz görülme oranını $\% 7,8$, Uzun ve arkadaşları $\% 14$, Çağlar ve arkadaşları ise \%16,4 olarak bildirmişlerdir8,13,14. Ülkemizde yapılan diğer çalışmalarla benign göz kapak tümörlerinin görülme oranı, yerleşim yeri ve cinsiyet dağılımı uyumlu bulunmuştur.

Çalışmamızda benign göz kapağı tümörlerinde yaş ortalaması 47,89 ve ortalama tümör boyutu $0,66 \mathrm{~cm}$ olarak değerlendirildi. Uzun ve arkadașları benign göz kapağı tümörlerinin en sık 50-60 yaş arasında (\%29), Çağlar ve arkadaşları ise benign kapak tümörlerin genellikle 40-60 yaş arasında görüldügünü bildirmişlerdir ${ }^{13,14}$. Çalışmamızda benign göz kapak tümörleri sıklıkla üst kapakta yerleşim göstermekteydi. Literatürdeki birçok çalışmada da benign kapak tümörlerinin sıklıkla üst kapakta yerleşim gösterdiği bildirilmiştir ${ }^{12-14}$.

Çalışmamızda malign göz kapak tümörlerinin oranı \%26,6 olarak belirlendi. Deprez ve arkadaşları malign tümör sıklığını \%16 olarak, $\mathrm{Xu}$ ve arkadaşları \%13,8; Pornpanich ve arkadaşları $\% 10,8$ oranında bildirmişlerdir ${ }^{10-12}$. Ülkemizde yapılan çalışmalarda ise malign göz kapak tümör görülme sıklığı \%6,1-31,8 olarak bildirilmiştir ${ }^{3,7,8,15}$. Çalışmamızda en sık görülen malign göz kapağı tümörü bazal hücreli karsinom idi. Bazal hücreli karsinomun tüm tümörler içerisinde görülme sıklı̆̆ı \%20,2 olup, malign tümörler içerisinde görülme oranı \%84,6 idi. Ülkemizde yapılan diğer çalışmalarda BHK \%57,6- 91,3 oranlarında en sık görülen malign göz kapak tümörü olarak bildirilmiștir $7,8,14,16$. Çalışmamızda BHK sıklıkla kadınlarda izlenmekte olup $(\% 63,6)$ yaş ortalaması 68,22 idi ve sıklıkla kitleler alt kapakta $(\% 72,7)$ yerleşim göstermekteydi. Tzoutzos ve arkadaşları yapmış oldukları çalışmada BHK' ların kadınlarda ve alt kapakta daha sık ve ortalama 70,18 yaşlarında görüldügünü bildirmişlerdir ${ }^{17}$. Günalp ve arkadaşları 1100 olgudan oluşan serilerinde BHK'ların en sık 60-70 yaşları arasında izlendiğini bildirmişlerdir ${ }^{18}$. Erdoğan ve arkadaşları BHK' ların ortalama 59,43 yaşında ve $\% 80,9$ oranında alt kapakta yerleștiğini, Çağlar ve arkadaşları BHK'nun ortalama 65,86 yaşında ve en sık alt kapakta $(\% 65,5)$ görüldügünü bildirmişlerdir8,14. Ülkemizde yapılan diğer çalışmalar ve literatürdeki diğer çalışmalarla BHK'ların görülme yaşı ve yerleşim yeri benzerlik göstermektedir. BHK'lar daha çok ileri yaşlarda görülmekle beraber, çocuk ve gençlerde de görülebilmektedir. BHK'lara açık tenlilerde, çiftçilerde ve aşırı güneş banyosu yapmış olanlarda normal popülasyona göre daha sık rastlanır ${ }^{19}$. Bizim çalışmamızda da iki 
bazal hücreli karsinom olgusu 50 yaş altında olup, açık tenli kişilerdi. Çalışmamızda skuamöz hücreli karsinom ve sebase karsinom görülme oranı \%1,8 idi. Gündoğan ve arkadaşları skuamöz hücreli karsinom görülme oranını $\% 0,06$, Çağlar ve arkadaşları ise $\% 0,6$ oranında bildirmişlerdir9,14. Çalışmamızda iki olguda skuamöz hücreli karsinom izlenmiş olup biri alt kapak diğeri üst kapak yerleşimli idi. Literatürdeki diğer çalışmalara bakıldığında skuamöz hücreli karsinom sıklıkla alt kapakta yerleşim göstermekteydi ${ }^{8,14,20}$.Çalışmamızda iki olguda sebase hücreli karsinom izlenmiş olup, olgulardan birinin yaşı 36 olup literatürde gözlenen yaş ortalamasından daha genç idi ${ }^{11,21}$. Literatüre bakıldığında Asya ülkelerinde yapılan çalışmalarda sebasöz karsinomlar daha sık izlenirken, Avrupa ülkelerinde yapılan çalışmalarda ise bazal hücreli ve skuamöz hücreli karsinomların sık izlendiği bildirilmiştir1,11,21,22.

Çalışmamızda benign lezyonlar sıklıkla üst kapakta $(\% 46,7)$ izlenirken, premalign ve malign tümörler sıklıkla alt kapakta $(\% 75,9)$ yerleșim göstermekteydi. Coroi ve arkadaşları benign ve malign kapak tümörü olan 471 olgudan oluşan çalışmalarında; benign kapak tümörlerini daha çok üst kapakta, malign kapak tümörlerini daha sık olarak alt kapakta bulmuşlardır ${ }^{23}$. Literatüre bakıldığında malign tümörler sıklıkla 60 yaş ve üzerinde izlenmektedir ${ }^{23,24}$. Bununla beraber olgularımızda bazal hücreli karsinom tanısı alan 2 hastanın yaşlarının 45 ve 48 , sebase bez karsinomu olan 1 hastanın yaşının 36 olması genç hastalarda da mutlaka malignite olasılığını düşünmemiz gerektiği hususunda önem arz etmektedir.

Çalışmamızda klinik ön tanısı benign düşünülen 86 kitlenin $4(\% 4,6)$ 'ü premalign ve 5'i malign $(\% 5,81)$ olarak patolojide değerlendirildi. Margo yapmış olduğu çalışmada, iyi huylu kitle ön tanısıyla çıkartılan lezyonların \%4,6'sının kötü huylu olduğu bildirmiștir 5 . Klinik ön tanısı benign olarak düşünülen lezyonlarda malignite olasılı̆ı̆ her zaman göz önünde bulundurularak histopatolojik inceleme mutlaka yapılmalıdır.

\section{SONUC}

Çalışmamızda göz kapağı lezyonlarının klinik ve histopatolojik analizi yapılmıştır. Lezyonların dağılımı diğer çalışmalarla benzerlik göstermekle birlikte, ırk, yaș, cinsiyet, yaşanılan yer, güneş ışı̆̆ maruziyeti gibi çevresel faktörler kitlelerin histopatolojik tanı dağılımında etkili olabilmektedir. Klinik olarak benign düşünülen kitlelerde malignite olasılığı mutlaka akılda bulundurulmalı ve eksize edilen tüm kitleler patolojik olarak değerlendirilmelidir.

Etik Kurul Kararı: Çalışmamız için Etik Kurul onayı alındı ve çalışma Helsinki Bildirgesi'ne uygun olarak yürütüldü.

Çıkar Çatışması Beyanı: Yazarlar çıkar çatışması olmadığını bildirmişlerdir.

Finansal Destek: Bu çalışma her hangi bir fon tarafından desteklenmemiştir.

Declaration of Conflicting Interests: The authors declare that they have no conflict of interest.

Financial Disclosure: No financial support was received.

\section{KAYNAKLAR}

1. Chi MJ, Baek SH. Clinical analysis of benign eyelid and conjunctival tumors. Ophtalmologica 2006; 220: 43-51.

2. Yin VT, Merritt HA, Sniegowski M, et al. Eyelid and ocular surface carcinoma: diagnosis and management. Clin Dermatol 2015; 33: 159-69.

3. Karabulut HH, Karabulut YY, Şenel E, et al. Göz Kapağı Tümörlerinin Histopatolojik ve Demografik Özellikleri. Turk J Dermatol 2014; 4: 197-201. 
4. Kumar R. Clinicopathologic study of malignant eyelid tumours. Clin Exp Optom 2010; 93: 224-7.

5. Margo CE. Eyelid tumors: accuracy of clinical diagnosis. Am J Ophthalmol 1999; 128: 635-6.

6. Kersten RC, Ewing-Chow D, Kulwin DR, et al. Accuracy of clinical diagnosis of cutaneous eyelid lesions. Ophthalmology 1997; 104: 47984.

7. Kandemir NO, Barut F, Bektaş S, et al. Göz Kapağı ve Konjonktivanın Tümörleri ve Tümör Benzeri Lezyonları. Turk Patoloji Derg 2009; 25: 112-7.

8. Erdoğan H, Demirci Y, Dursun A, et al. Göz Kapağı Kitlelerinin Histopatolojik Bulguları. Türkiye Klinikleri J Opthalmol 2013; 22: 75-80.

9. Gündoğan FC, Yolcu U, Tas A, et al. Eyelid Tumors: Clinical Data from an Eye Center in Ankara, Turkey. Asian Pac J Cancer Prev 2015; 16: 4265-9.

10. Deprez M, Uffer S. Clinicopathological features of eyelid skin tumors. A retrospective study of 5504 cases and review of literatüre. Am J Dermatopathol 2009; 31: 256-62.

11. Xu XL, Li B, Sun XL, et al. Eyelid neoplasms in the Beijing Tongren Eye Centre between 1997 and 2006. Ophthalmic Surg Lasers Imaging 2008; 39: 367-72.

12. Pornpanıch K, Chındasub P. Eyelid tumors in Siriraj Hospital from 2000-2004. J Med Assoc Thai 2005; 88: 11-4.

13. Uzun A, Gündüz K, Erden E, et al. İyi Huylu Göz Kapağ Histopatolojik Tanı. Turk J Ophthalmol 2012; 42: 43-6.

14. Çağlar Ç, Güney G, Dönmez O, et al. Göz Kapağı Tümörlerinde Histopatoloji Sonuçları. Türkiye Klinikleri J Ophthalmol 2017; 26: 2531.

15. Çömez AT, Akçay L, Özgür Ö, et al. Göz Kapağı Kitlelerinin Histopatolojik ve
Epidemiyolojik Değerlendirilmesi. T. Oft. Gaz 2007; 37: 84-92.

16. Kurt A, Mutlu SN, Yener Hİ, et al. Primer Göz Kapağı Tümörlerinde Histopatoloji Sonuçları. Dicle Med J. 2015; 42: 72-7.

17. Tzoutzos K, Batistatou A, Kitsos G, et al. Retrospective clinicopathological study of 129 cancerous and 18 Precancerous lesions of the eyelids in North-Western Greece. Int Ophthalmol 2017; 37: 203-8.

18. Günalp İ, Akbaş F. Göz Kapağının Bazal Hücreli Karsinomu: 1100 Olguda Klinik Bulgular ve Tedavi Yaklaşımları. MN Oftalmoloji 1996; 3: 292-301.

19. Lawrence CM. Mohs' micrographic surgery for basal cell carcinoma. Clin Exp Dermatol 1999; 24: 130-3.

20. Donaldson MJ, Sullivan TJ, Whitehead KJ, et al. Squamous cell carcinoma of the eyelids. Br J Ophthalmol 2002; 86: 1161-5.

21. Jangir MK, Kochar A, Khan NA, et al. Profile of Eyelid Tumours: Histopathological Examination and Relative Frequency At A Tertiary Centre In North-West Rajasthan. Delhi J Ophthalmol 2017; 28: 30-5.

22. Halon A, Blazejewska M, Sabri H, et al. Tumors and tumor-like lesions of eyelids collected at Department of Pathological Anatomy Wroclaw Medical University between 1946 and 1999. Klinika Oczna 2005; 107: 4758.

23. Coroi MC, Roşca E, Mutiu G, et al. Eyelid Tumors: histopathological and clinical study performed in County Hospital of Oradea between 2000-2007.Rom J Morphol and Embryol 2010; 51: 111-5.

24. Wang $\mathrm{CY}$, Zhang $\mathrm{HN}, \mathrm{Wu} \mathrm{H}$, et al. Clinicopathologic features and prognostic factors of malignant eyelid tumors. Int J Ophthalmol 2013; 6: 442-7. 